Hydrol. Earth Syst. Sci. Discuss., 5, 1511-1531, 2008 www.hydrol-earth-syst-sci-discuss.net/5/1511/2008/

(C) Author(s) 2008. This work is distributed under the Creative Commons Attribution 3.0 License.
Hydrology and Earth System Sciences Discussions

Papers published in Hydrology and Earth System Sciences Discussions are under open-access review for the journal Hydrology and Earth System Sciences

\title{
Scale effects on runoff generation in meso-scale and large-scale sub-basins in the Luanhe River Basin
}

\section{P. Feng and J. Z. Li}

School of Civil Engineering, Tianjin University, Tianjin 300072, China

Received: 4 April 2008 - Accepted: 10 May 2008 - Published: 19 June 2008

Correspondence to: J. Z. Li (Ihyyying@163.com)

Published by Copernicus Publications on behalf of the European Geosciences Union.

\section{HESSD}

$5,1511-1531,2008$

Scale effects on runoff generation

P. Feng and J. Z. Li

Title Page

Abstract

Introduction

Conclusions

References

Tables

Figures

14

$\rightarrow$

$\triangleleft$

Back

Close

Full Screen / Esc

Printer-friendly Version

Interactive Discussion 


\section{Abstract}

The scale effects on runoff coefficients have been observed by several researchers on plots or small watersheds, however, little research has been done on meso-scale and large-scale catchments. So six meso-scale and large-scale sub-basins of the Luanhe 5 river basin, in northeast of China, were selected for calculating the runoff coefficients of single event during 1956-2002. An obvious reduction in average runoff coefficients from 0.43 (Liuhe basin) to 0.10 (Luanhe basin) was found with increasing basin area. And for the annual runoff coefficients from 1956 to 2002, the same trend was also observed. In addition, runoff coefficients varied wildly from one rainstorm to the other. soil and fills in the macropores of the soil, and after runoff generation rainfall infiltrates during the routing process. And the spatial variability of rainfall, the groundwater discharge ability can also lead to runoff coefficients reduction with the increasing basin area. The study on the scale effects on runoff coefficient is very important to develop a physically-based hydrological model and parameter estimation on different scales.

\section{Introduction}

The effect of different scales on hydrologic variables is one of the major unresolved issues in the hydrological sciences (McGlynn et al., 2004), and also in other subjects such as meteorology, climatology, agrology and sociology (Bloschl and Sivapalan,

20 1995). Although the basic properties of scale and scaling problems have been understood clearly, research on hydrological processes such as infiltration, evapotranspiration, surface runoff and undersurface runoff has been conducted on small temporal and spatial scales, and little on meso-scale and large scale basins, so the theory of expanding hydrological processes from small scale to large scale is immature.

25 Runoff coefficient is an important factor to describe runoff dynamics. Several authors have done some observations and experiments of scale effect on runoff coefficient on

\section{HESSD}

$5,1511-1531,2008$

Scale effects on runoff generation

P. Feng and J. Z. Li

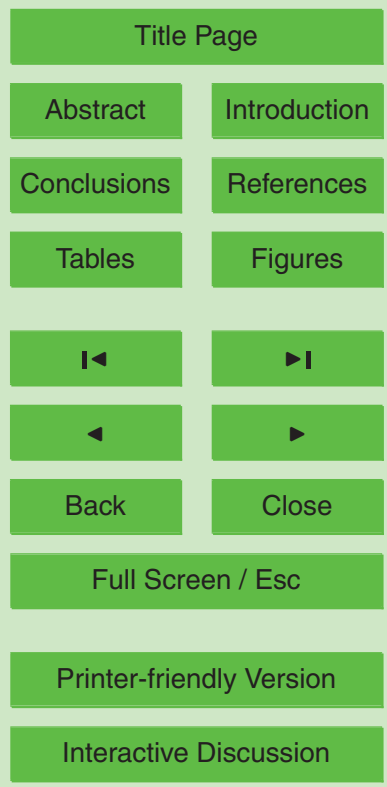

Interactive Discussion 
plots or small watershed. Mathier and Roy (1996) found no important variation with scale under crusted soil conditions with low to medium rainfall intensities when studying the effect of different slope lengths (from 5 to $55 \mathrm{~m}$ ) on the parameters of a sediment equation for sheetwash. Accordingly Bissonnais et al. (1998), on the basis of contin5 uous runoff measurements carried out at $1,20,500$ and $900000 \mathrm{~m}^{2}$, concluded that the scale ratios were highly variable depending on surface state conditions. When the monitoring surveys involve catchments larger than $1 \mathrm{~km}^{2}$, the scale effects can be even more divergent. On the basaltic plateau of southern Brazil, dos Reis Castro et al. (1999), after the comparison of runoff coefficients at different scales, ranging from 10 small plots to a catchment of several $\mathrm{km}^{2}$ indicated that processes could emerge with scale, as the relative decrease of runoff on the slopes could lead to an increase in subsurface flow. Joel et al. (2002), who observed a decrease in the runoff coefficient with increasing plot size (from 0.25 to $50 \mathrm{~m}^{2}$ ) even during period of continuous runoff. Van de Giessen et al. (2000) and Stomph et al. (2002) also observed a clear reduction of the runoff coefficient per unit slope length; and they showed that the importance of the reduction varied enormously according to the temporal dynamics of the rainfall-runoff events. Parsons et al. (2006) found an inverse relationship between runoff coefficient and plot length on eight plots ranged in length from $2 \mathrm{~m}$ to $27.78 \mathrm{~m}$. Based on the 345 measured rainfall-runoff events, Cerdan et al. (2004) demonstrated that in terms of hydrological processes, a catchment cannot be considered as the sum of individual fields and that simple linear upscaling procedures would not be valid.

In this paper, runoff coefficients obtained from several rainfall-runoff processes in the six sub-basins of the Luanhe river basin, which are meso-scale or large-scale basins, were compared to testify the results illustrated by the afore-mentioned studies.

25 And we analyzed the reasons for the runoff coefficients reduction with the increasing basin area. This study will provide reference to develop a physically-based hydrological model and parameter estimation on different scales
HESSD

5, 1511-1531, 2008

Scale effects on runoff generation

P. Feng and J. Z. Li

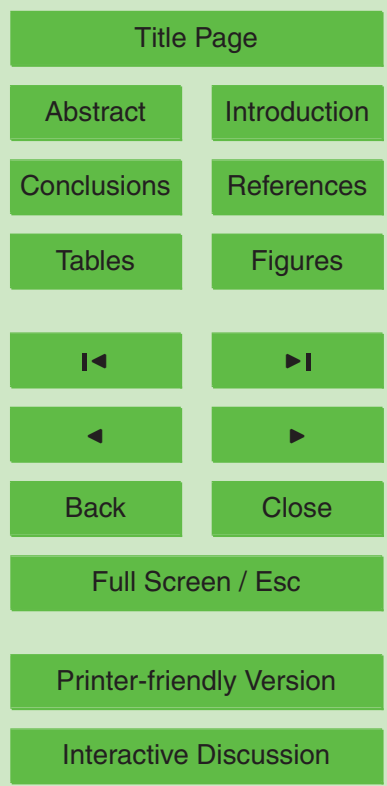




\section{Materials}

\subsection{Study area}

HESSD

Luanhe river basin, located in the northeast part of China, has a drainage area of $33700 \mathrm{~km}^{2}$, and lies between $115^{\circ} 40^{\prime}-119^{\circ} 20^{\prime} \mathrm{E}$ and $39^{\circ} 10^{\prime}-42^{\circ} 35^{\prime} \mathrm{N}$ with the ele-

5 vation ranging from 2 to $2205 \mathrm{~m}$ (the average elevation is $766 \mathrm{~m}$ ). About $98 \%$ of the drainage area is mountainous region and about $2 \%$ is plain. The watershed receives an average precipitation of $560 \mathrm{~mm}$, mostly in the summer(70-80\%), especially in July and August, and an average runoff of $46.94 \times 10^{8} \mathrm{~m}^{3}$ per year. The flood is often resulted from rainstorm, and also in July and August. Because of the short duration and high intensity of the rainstorms, the flood is of high peak and large amount and the duration of the flood is between 3 and 6 days. The average temperature is between -0.3 and $11^{\circ}$, and gradually lower from southeast to northwest. The average potential evapotranspiration reaches $950-1150 \mathrm{~mm}$ per year, and the highest can reach $1801 \mathrm{~mm}$ per year. The average absolute humidity is $9.6 \mathrm{mba}$, and the average relative humidity is 15 60-70\%.

In this study, Liuhe sub-basin, Luanhe sub-basin, Yixunhe sub-basin, Wuliehe subbasin, Laoniuhe sub-basin and Baohe sub-basin, which are the sub-basins of the Luanhe river basin are taken as the study area (Fig. 1). The main hydrological stations are located at the outlet of each sub-basin. The sub-basins range in area from 626 to $20 \quad 17100 \mathrm{~km}^{2}$.

\subsection{Hydrometerology data}

Precipitation data mostly covers the period from 1956-2002 with the exception of Laoniuhe sub-basin, where the data available are from 1968 to 2002.

Runoff data for Liuhe sub-basin are available from 1957-2002. Also, the discharge data for Wuliehe sub-basin are available from 1956-2002. Discharge data of the Luanhe, Yixunhe and Xingzhouhe sub-basins are available from 1958-2002, 1956-2001

Scale effects on runoff generation

P. Feng and J. Z. Li

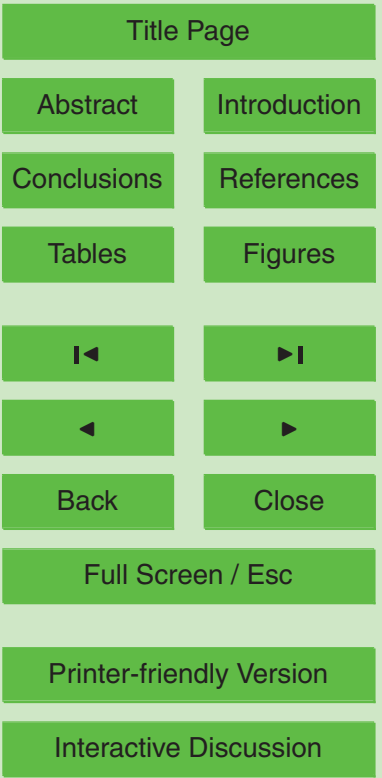

Interactive Discussion 
and 1960-2002 respectively. However, data of Laoniuhe basin is available from 1968 to 2002.

We selected several single events from the time series to make an analysis of the scale effect on runoff coefficients.

\section{HESSD}

$5,1511-1531,2008$

Scale effects on runoff generation

P. Feng and J. Z. Li

Several rainfall-runoff processes in the six sub-basins of the Luanhe river basin were selected for the analysis of scale effects on runoff coefficient from 1956 to 2002. Then the runoff coefficient of each rainfall-runoff process was calculated to obtain the average runoff coefficient of each sub-basin. The results are shown in Table 2 and Fig. 2

From the average runoff coefficients of the six sub-basins of Luanhe basin shown in Table 2, a general decrease trend in runoff coefficients with increasing basin area is observed, especially in Luanhe and Yixunhe sub-basins which are of larger area, the runoff coefficients are more smaller than other sub-basins. For example, on 12 December 1973 the Luanhe sub-basin received an average precipitation of $164.64 \mathrm{~mm}$, whereas the runoff coefficient is just 0.074 . Compared with Liuhe sub-basin which is of the smallest drainage area and the largest runoff coefficient of 0.43 , the average runoff coefficient of the Luanhe sub-basin is just one fourth of that of Liuhe basin.

With the precipitation depth being larger and duration longer, more precipitation converted to runoff because of the saturated area increasing during the rainfall process which leads to the small differences in runoff coefficients in the six sub-basins. For example, on 27 July 1978, the total rainfall depth was $106.66 \mathrm{~mm}$ and the runoff coefficient was 0.32 in Liuhe basin, whereas the total rainfall depth was $100.73 \mathrm{~mm}$ and the runoff coefficient was 0.24 in Wuliehe basin. If the precipitation depth is low with a high intensity and short duration, the differences in runoff coefficients between the subbasins are obvious, for example, on 11 August 1990, the rainfall amount was $52.85 \mathrm{~mm}$

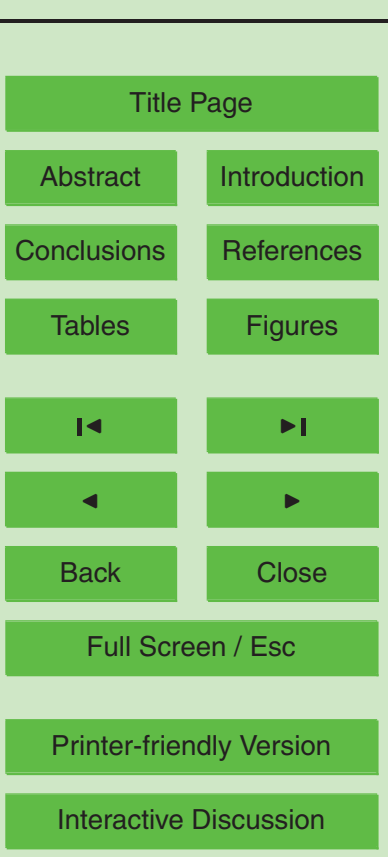

1515 
in $6 \mathrm{~h}$ in Liuhe basin and the runoff coefficient was 0.16 , while in Wuliehe basin the runoff coefficient was 0.08 under the rainfall amount of $50.51 \mathrm{~mm}$.

The antecedent soil moisture is a very important parameter to influence runoff coefficient, and it can be reflected from the precipitation amounts in the preceding 7 days 5 and the initial flow. In the same basin, runoff coefficient will be larger if there is a larger preceding 7-day rainfall amount and initial flow; and the same results can be obtained with high precipitation intensity and short duration. But Laoniuhe basin is an exception in the statistical results. The drainage area of Laoniuhe basin is smaller than that of Wuliehe basin and Baohe basin, whereas the average runoff coefficient is smaller than 10 that of the two sub-basins. The reasons for this are that the statistical preceding 7day precipitation amounts were small (the average was $33.6 \mathrm{~mm}$, and in Baohe basin and Wuliehe basin the average preceding 7-day precipitation amounts were 36.6 and $45.7 \mathrm{~mm}$, respectively). So the low antecedent soil moisture is the main reason for the small runoff coefficient in Laoniuhe basin.

15 For the average annual runoff coefficients from 1956 to 2002 in each sub-basin, the same trend as single event can be seen in Fig. 3.

\subsection{Reasons for runoff coefficient decrease}

Scale effects are often associated with spatial variability of soil physical properties (Bonell and Williams, 1986; Julien and Moglen, 1990). Julien and Moglen (1990) 20 pointed out that the spatial variability of the soil influenced runoff coefficients for the precipitation of short duration and high intensity, while little impact for the ones of long duration. And in the Luanhe river basin, the flood was often caused by precipitation of long duration, so in this paper, the spatial variability of soil properties was not considered.

HESSD

$5,1511-1531,2008$

Scale effects on runoff generation

P. Feng and J. Z. Li

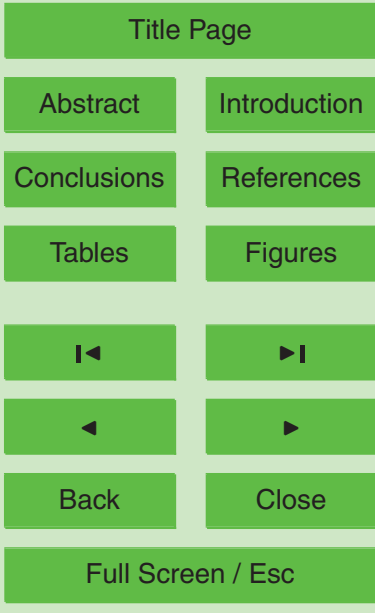

Printer-friendly Version

Interactive Discussion 


\subsubsection{The spatial variability of rainfall}

The spatial variability of rainfall causes the spatial variability of runoff generation and different contributing area. The spatial coefficient of variation $(C V)$ was defined by:

$C V=\sqrt{\frac{\sum_{i=1}^{n}\left(K_{i}-1\right)^{2}}{n-1}}$

HESSD

$5,1511-1531,2008$

$5 K_{t}=\frac{H_{t}}{\bar{H}}$

where $K_{i}$ is the modular coefficient, $n$ is the number of rain gages, $H_{i}$ is the rainfall depth at individual rain gage, and $\bar{H}$ is the average rainfall depth of all the rain gages.

The spatial variability of rainfall for different rainfall events and in different catchments is different. So we calculated the average coefficient of variations in the six sub-basins 10 of the Luanhe watershed (Table 3).

It is shown that the average spatial variability of rainfall increases with the increase of the sub-basin size, and according to Zhang et al. (2004), the smaller CV, the larger runoff coefficient for similar precipitation (similar precipitation depth, intensities). So we can conclude that the spatial variability of precipitation is one of the reasons for runoff decrease with increase of the sub-basin size.

\subsubsection{The impact of infiltration}

Most authors have attributed the scale dependency in hillslope runoff to spatial variability in infiltration (Sharma et al., 1980; Dubreuil, 1985; Williams and Bonnell, 1988; Wilcox et al., 1997). Important spatially variable parameters are hydraulic conductivity and sorptivity governing infiltration, microtopography, which sets the amount of surface storage before runoff begins, and slope, vegetation or surface roughness, which

\section{Scale effects on runoff generation}

P. Feng and J. Z. Li

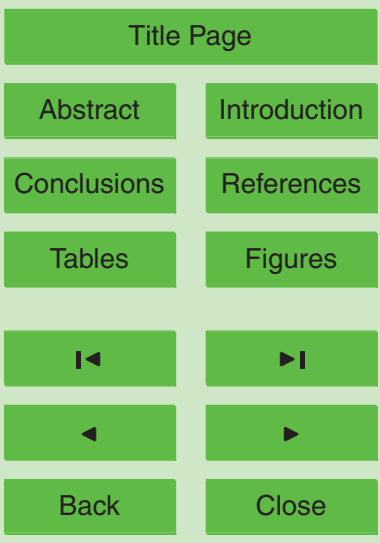

Full Screen / Esc

Printer-friendly Version

Interactive Discussion 
determine the depth and velocity of overland flow. The spatial variability of these parameters does not necessarily reduce runoff from larger areas but, in general, a larger area means a higher chance of extreme values and this tends to reduce runoff (Van de Giessen et al., 2000).

$5 \quad$ We think that as the catchment scale increases, the response time increases, so there is more opportunity for infiltration. Figure 4 shows the runoff coefficients as a function of runoff response time for a comparison between the six sub-basins. We can find that if the response time remains unchanged, Luanhe has the smallest runoff coefficients, and Liuhe has the largest runoff coefficients.

10 At the beginning of the storm, the rainfall is absorbed in the soil and fills in the macropore of the soil, and after runoff generation rainfall infiltrates during the routing process. So there is a clear lag time from the beginning of precipitation to the time of runoff generation, and this lag time reflects the speed of runoff generation. Recession processes is another important component of hydrological processes. The recession process of 15 surface runoff ends at the turning point, so the infiltration during the recession is also a part of rainfall loss. Under the simplification of the infiltration rate independent of the overland flow depths, Wallach et al. (1997) simulated the rainfall-runoff processes, and the simulations showed that higher infiltration rates and lower overland flow depths were obtained during the rising stage of the hydrograph; during the recession period, the model predicted lower infiltration rates and higher overland flow. This indicates the importance of the infiltration during the recession period.

The rainfall amount before the rising point of runoff process and the recession duration were calculated, and the averages are shown in Table 4.

Table 4 shows that the larger the catchment area, the more rainfall amount needed 25 for runoff generation, i.e. the average rainfall amount before runoff generation is $4.68 \mathrm{~mm}$ in Liuhe basin, whereas $14.03 \mathrm{~mm}$ in Luanhe basin, which illustrates that even though runoff was generated before the rising point of the runoff process, this generated runoff will infiltrate during the routing process or it needed long time traveling to the outlet. For the recession duration, the larger the catchment area is, the longer the
HESSD

5, 1511-1531, 2008

Scale effects on runoff generation

P. Feng and J. Z. Li

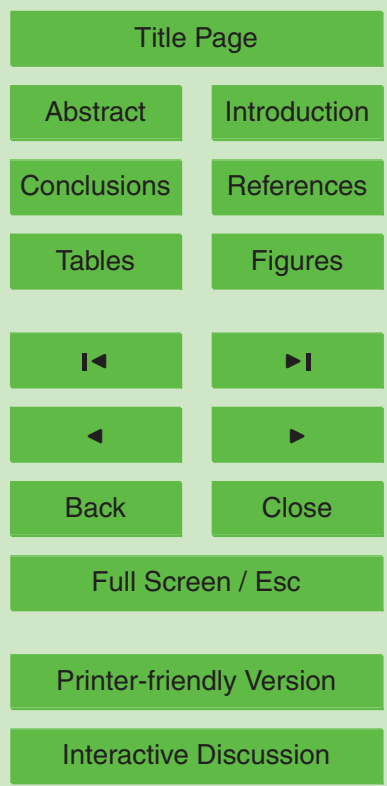

Interactive Discussion 
recession process of the surface runoff, resulting in more infiltration in routing process. So Table 4 reflects that temporal variation of surface runoff is the main cause of runoff coefficients decreasing with the increasing catchment area.

\subsubsection{The groundwater discharge ability of the soil}

5 The discharge ability of the soil largely influences the subsurface flow. We selected the the groundwater discharge per unit area during the period without precipitation to represent the discharge ability of the soil and they are shown in Table 5 for the six sub-basins.

Table 5 shows that during the period without precipitation, the groundwater discharge 10 per unit area decreases with the increase of the catchment area, leading to the subsurface runoff generation ability reduction. This maybe results from that during rainfall period, the air in the soil pores can not escape, resulting in the reduction of soil conductivity.

\subsubsection{Other possible reasons}

15 Climate, slope and soil types may affect runoff generation depth. Influenced by topography, precipitation decreases from south to north, that is, Luanhe receives the lowest precipitation each year about $450 \mathrm{~mm}$, Yixunhe receives about 457 520 mm per year, Wuliehe 500 600 mm, and Liuhe, Laoniuhe, Baohe receive the highest precipitation each year about $500 \sim 800 \mathrm{~mm}$. So we can say Luanhe sub-basin is the driest of the basins, and Liuhe is the most humid of the basins, which may result in the smallest runoff coefficient in Luanhe sub-basin and the largest runoff coefficient in Liuhe subbasin.

Steep slopes seem to produce more runoff, however, it is not true in Luanhe basin. The slope becomes flatter from north to south in Luanhe basin, that is Luanhe subbasin has the steepest slope about 1/1. Yixunhe sub-basin has an average slope about 1/1, too. Liuhe, Baohe and Laoniuhe has the slope between 1/1.19 to 1/2.75. So

\section{HESSD}

$5,1511-1531,2008$

Scale effects on runoff generation

P. Feng and J. Z. Li

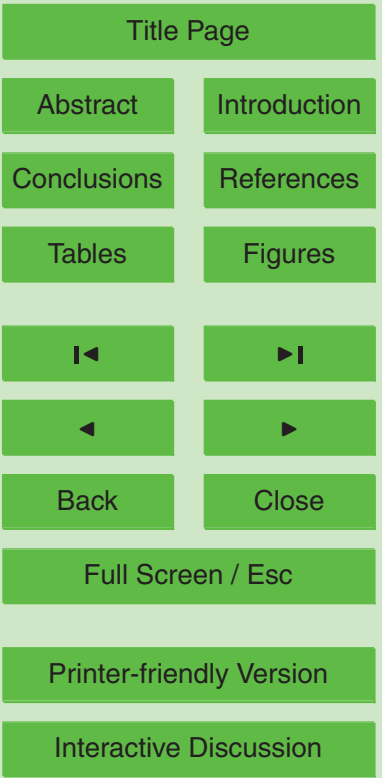


the conclusion can be drawn that slope is not the cause of runoff decrease with basin area in Luanhe basin.

The soil types in Luanhe sub-basin mainly include forest soil, black soil, chestnut soil and meadow soil, which contain more organism and more infiltration, while in other five 5 sub-basins cinnamon soil, brown soil and alluvial soil are dominant and less land cover leading to less infiltration. Therefore, Luanhe sub-basin has more infiltration than other five sub-basins.

\section{Conclusions}

Runoff coefficient is an important factor to describe runoff dynamics. In this paper, we 10 selected six meso-scale and large-scale sub-basins of the size from $626 \mathrm{~km}^{2}$ (Liuhe sub-basin) to $11700 \mathrm{~km}^{2}$ (Luanhe sub-basin) for the runoff coefficients calculation, and the following conclusions can be drawn.

(1) A clear reduction was observed from 0.43 (Liuhe sub-basin) to 0.10 (Luanhe subbasin) with the increasing basin area, which is also a rule for the annual runoff coeffi15 cients. We can see the total runoff generated in a basin really cannot be considered as the sum of sub-basins, but a non-linear relationship with the basin area.

(2) The spatial variability of rainfall is one of the reasons leading to runoff coefficients variation. It was shown that the average spatial variability of rainfall increases with the increase of the sub-basin size, resulting in the runoff coefficients reduction with the 20 increase of basin size.

(3) Infiltration during rainfall is an important factor to control the runoff coefficients. The average time for runoff initiation increases with the increase of basin size, which means before runoff initiation the infiltration amount increases with the increase of basin size. And during the runoff routing, the infiltration continues. The statistical analysis of the routing time for each sub-basin illustrates that there is more infiltration amount for the larger basin.

(4) The groundwater discharge ability of the soil can be the factor influencing the

HESSD

$5,1511-1531,2008$

Scale effects on runoff generation

P. Feng and J. Z. Li

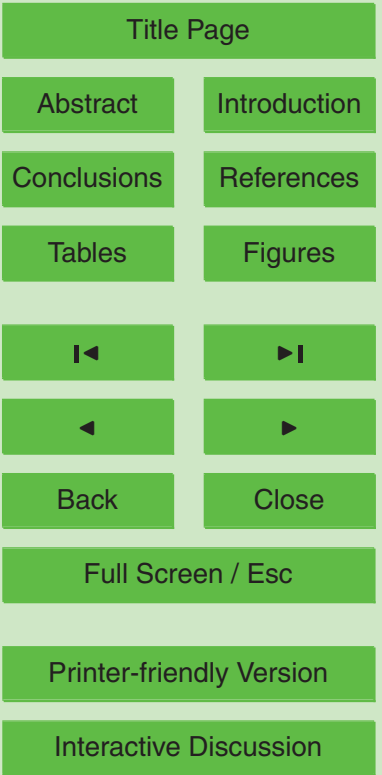


groundwater depth. The connectivity and conductivity of the soil will be reduced with the increase of basin area, so the groundwater discharge per unit area will be less for the larger basin.

(5) Climate may be a cause of runoff coefficients reduction with basin area increase, 5 but slopes and soil types would not be the main reasons.

As analyzed above, the scale effects of hydrological processes are very obvious, and some hydrological parameters will change in different basin area. Therefore, study on the hydrological processes should be conducted on different area of different scales to make provision for physical hydrological models.

10 Acknowledgements. This work was supported by National Natural Science Foundation of China. We are also grateful to Water Resources Management Centre of Tianjin for providing the hydrological data.

\section{References}

Bloschl, G. and Sivapalan, M.: Scale issues in hydrological modelling: a review, Hydrol. Process., 9, 251-290, 1995.

Bonell, M. and Willianms, J.: The generation and redistribution of overland flow on a massive oxic soil in a eucalypt woodland within the semi-arid tropics of North Australia, Hydrol. Process., 1, 31-46, 1986.

Castro, N. M. dos R., Auzet, A. V., Chevallier, P., et al.: Land use change effects on runoff and erosion from plot to catchment scale on the basaltic plateau of Southern Brazil, Hydrol. Process., 13, 1621-1628, 1999.

Cerdan, O., Le Bissonnais, Y., Govers, G., et al.: Scale effect on runoff from experimental plots to catchments in agricultural areas in Normandy, J. Hydrol., 299, 4-14, 2004.

Dubreuil, P. L.: Review of field observations of runoff generation in the tropics, J. Hydrol., 80, 237-264, 1985.

Joel, A., Messing, I., Seguel, O., et al.: Measurement of surface water runoff from plots of two different sizes, Hydrol. Process., 16, 1467-1478, 2002.

Juhen, Y. P. and Moglen, G. E.: Similarity and length scale for spatially varied overland flow, Water Resour. Res., 26, 1819-1832, 1990.
HESSD

$5,1511-1531,2008$

Scale effects on runoff generation

P. Feng and J. Z. Li

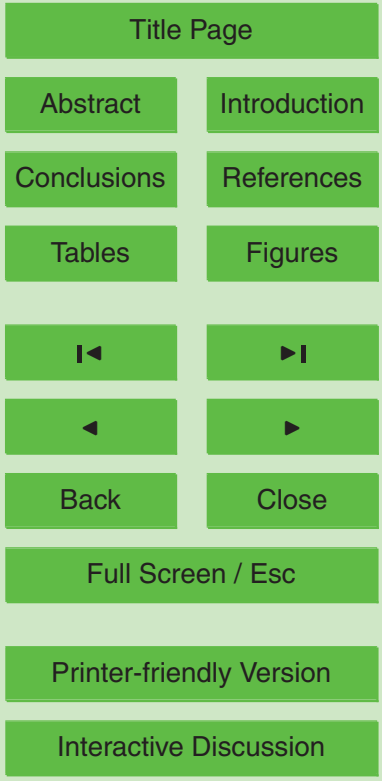


Le Bissonnais, Y., Benkhadra, H., Chaplot, V., et al.: Crusting, runoff and sheet erosion on silty loamy soils at various scales and upscaling from $\mathrm{m} 2$ to small catchments, Soil Till. Res., 46, 69-80, 1998.

Mathier, L. and Roy, A. G.: A study on the effect of spatial scale on the parameters of a sediment transport equation for sheetwash, Catena, 26, 161-169, 1996.

McGlynn, B. L., McDonnell, J. J., Seibert, J., et al.: Scale effects on headwater catchment runoff timing, flow sources, and groundwater-streamflow relations, Water Resour. Res., 40(7), W07504, doi:10.1029/2003WR002494, 2004.

Sharma, M. L., Gander, G. A., and Hunt, C. G.: Spatial variability of infiltration in a watershed, J. Hydrol., 45, 101-122, 1980.

Stomph, T. J., de Ridder, N., Steenhuis, T. S., et al.: Scale effects of Hortonian overland flow and rainfall-runoff dynamics: Laboratory validation of a process based model, Earth Surf. Proc. Land., 27, 847-855, 2002.

Wainwright, J. and Parsons, A. J.: The effect of temporal variations in rainfall on scale dependency in runoff coefficients, Water Resour. Res., 38(12), 1271, doi:10.1029/2000WR000188, 2002.

Wallach, R., Grigorin, G., and Rivlin, J.: The errors in surface runoff prediction by neglecting the relation ship between infiltration rate and overland flow depth, J. Hydrol., 200, 243-259, 1997.

Wilcox, B. P., Newman, B. D., Brandes, D., et al.: Runoff from a semiarid ponserosa pine hillslope in New Mexico, Water Resour. Res., 33, 2301-2314, 1997.

Williams, J. and Bonnell, M.: The influence of scale of measurement on the spatial and temporal variability of the Philip infiltration parameters - an experimental study in an Australian savannah woodland, J. Hydrol., 104, 33-51, 1988.

Van de Giessen, N. C., Stomph, T. J., and de Ridder, N.: Scale effects of hortonian overland flow and rainfall-runoff dynamics in a West African catena landscape, Hydrol. Process., 14, 165-175, 2000.

Zhang, X. S., Hao, F. H., and Zhang, J. Y.: Study on effect of uncertainty in spatial distribution of rainfall on runoff and sediment modeling, Res. Soil Water Cons., 11, 9-12, 2004 (in 30 Chinese).

HESSD

$5,1511-1531,2008$

Scale effects on runoff generation

P. Feng and J. Z. Li

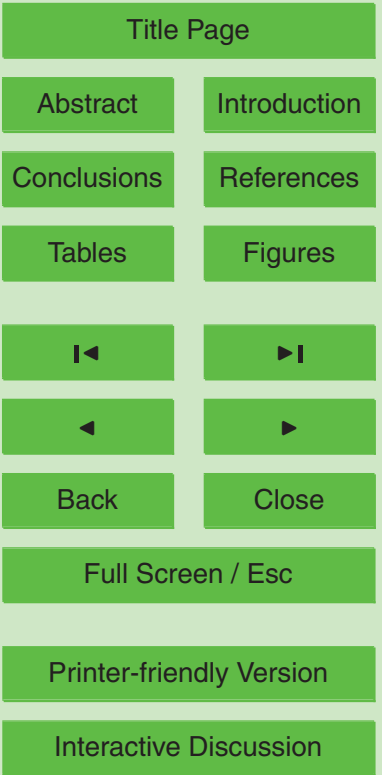




\section{HESSD}

$5,1511-1531,2008$

Scale effects on runoff generation

P. Feng and J. Z. Li

Table 1. The drainage area of the main sub-basins of Luanhe basin.

\begin{tabular}{llll}
\hline Sub-basins & Drainage area $\left(\mathrm{km}^{2}\right)$ & Sub-basins & Drainage area $\left(\mathrm{km}^{2}\right)$ \\
\hline Liuhe & 626 & Laoniuhe & 1615 \\
Yixunhe & 6761 & Baohe & 1661 \\
Wuliehe & 2460 & Luanhe (in Chengde) & 17100 \\
\hline
\end{tabular}

Title Page

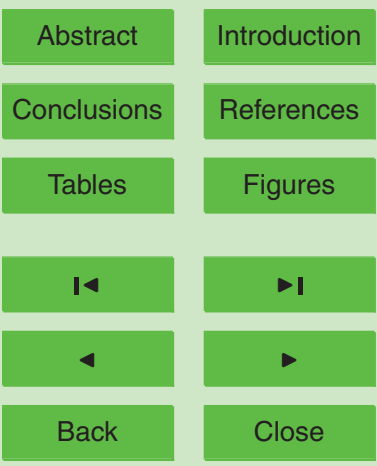

Full Screen / Esc

Printer-friendly Version

Interactive Discussion

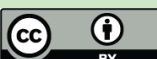




\section{HESSD}

$5,1511-1531,2008$

Scale effects on runoff generation

P. Feng and J. Z. Li

Table 2. Characteristics of the rainfall and runoff events of the six sub-basins of the Luanhe river basin.

\begin{tabular}{lllllll}
\hline Sub-basin & $\begin{array}{l}\text { No. of } \\
\text { events }\end{array}$ & $\begin{array}{l}\text { Average } \\
\text { precipitation } \\
(\mathrm{mm})\end{array}$ & $\begin{array}{l}\text { Average 7-day } \\
\text { precipitation before } \\
\text { the events }(\mathrm{mm})\end{array}$ & $\begin{array}{l}\text { Average initial } \\
\text { discharge } \\
\left(\mathrm{m}^{3} / \mathrm{s}\right)\end{array}$ & $\begin{array}{l}\text { Average runoff } \\
\text { depth } \\
(\mathrm{mm})\end{array}$ & $\begin{array}{l}\text { Average } \\
\text { runoff } \\
\text { coefficient }\end{array}$ \\
\hline Luanhe & 12 & 87.15 & 37.09 & 35.29 & 3.42 & 0.10 \\
Yixunhe & 12 & 71.90 & 38.65 & 32.87 & 8.72 & 0.12 \\
Wuliehe & 12 & 76.69 & 45.70 & 7.91 & 14.98 & 0.22 \\
Liuhe & 14 & 123.43 & 69.05 & 14.01 & 58.76 & 0.43 \\
Baohe & 12 & 84.82 & 36.55 & 16.22 & 22.96 & 0.31 \\
Laoniuhe & 12 & 66.93 & 33.63 & 8.75 & 11.67 & 0.18 \\
\hline
\end{tabular}

Title Page

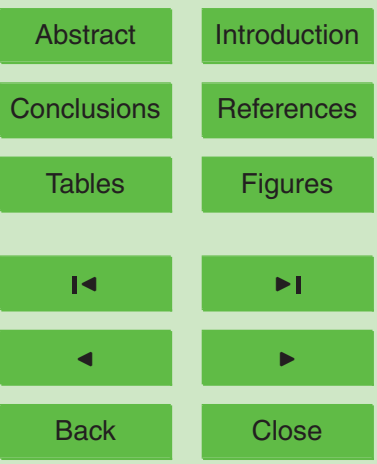

Full Screen / Esc

Printer-friendly Version

Interactive Discussion 


\section{HESSD}

$5,1511-1531,2008$

\section{Scale effects on} runoff generation

P. Feng and J. Z. Li

Title Page

Abstract

Introduction

Table 3. The rainfall coefficient of variation in the six sub-basins of the Luanhe river basin.

\begin{tabular}{lllllll}
\hline Sub-basins & Luanhe & Yixunhe & Wuliehe & Baohe & Laoniuhe & Liuhe \\
\hline CV & 0.53 & 0.49 & 0.15 & 0.34 & 0.29 & 0.20 \\
\hline
\end{tabular}

Conclusions

References

Tables

Figures

14

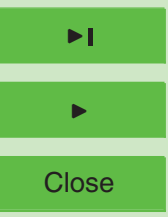

Back

Close

Full Screen / Esc

Printer-friendly Version

Interactive Discussion 


\section{HESSD}

$5,1511-1531,2008$

Scale effects on runoff generation

P. Feng and J. Z. Li

Table 4. The average rainfall before runoff generating and average recession duration after rainfall stops in the six sub-basins of the Luanhe river basin.

\begin{tabular}{lllllll}
\hline & Luanhe & Yixunhe & Wuliehe & Liuhe & Baohe & Laoniuhe \\
\hline $\begin{array}{l}\text { Average rainfall before } \\
\text { runoff generates }(\mathrm{mm})\end{array}$ & 14.03 & 13.37 & 9.39 & 4.68 & 6.95 & 6.08 \\
$\begin{array}{l}\text { Surface runoff } \\
\text { recession duration (h) }\end{array}$ & 51.6 & 48.9 & 43 & 32.9 & 36.3 & 35.7 \\
\hline
\end{tabular}

Title Page
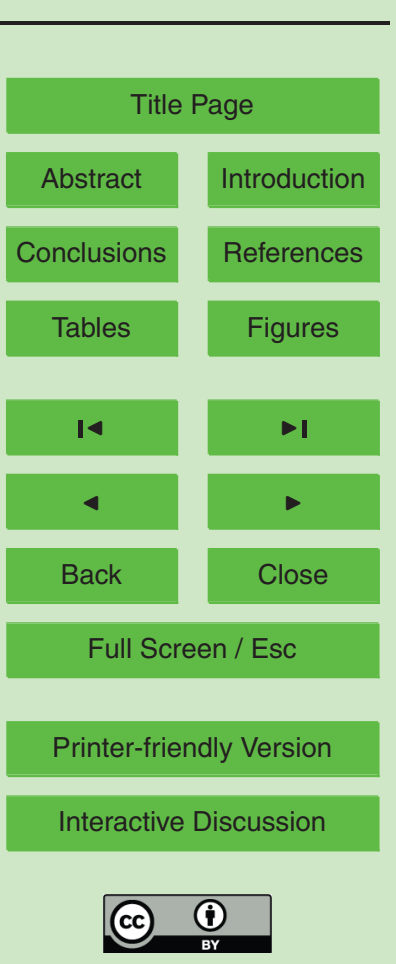


\section{HESSD}

$5,1511-1531,2008$

\section{Scale effects on} runoff generation

P. Feng and J. Z. Li

Table 5. The groundwater discharge per unit area during the period without precipitation for the six sub-basins of the Luanhe river basin.

\begin{tabular}{lllllll}
\hline Sub-basins & Luanhe & Yixunhe & Wuliehe & Baohe & Laoniuhe & Liuhe \\
\hline $\begin{array}{l}\text { The groundwater discharge per unit } \\
\text { area during the period without }\end{array}$ & 2.64 & 6.39 & 8.86 & 7.04 & 7.92 & 12.98 \\
precipitation $\left(10^{-4} \mathrm{~m}^{3} / \mathrm{s} / \mathrm{km}^{2}\right)$ & & & & & & \\
\hline
\end{tabular}

Title Page

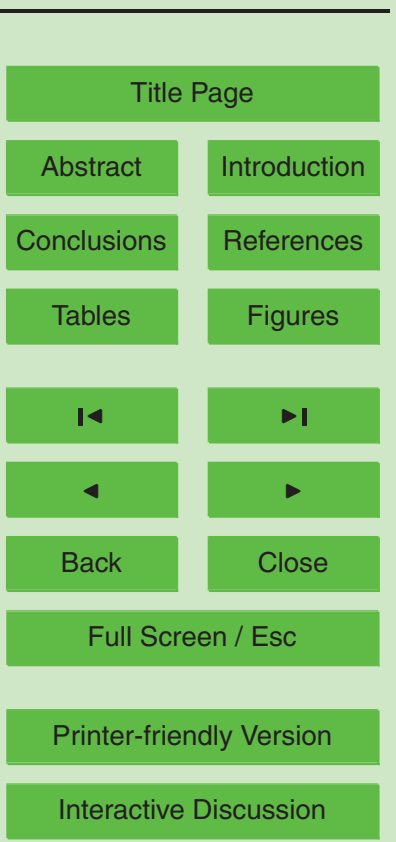

cC) (i) 


\section{HESSD}

5, 1511-1531, 2008

Scale effects on runoff generation

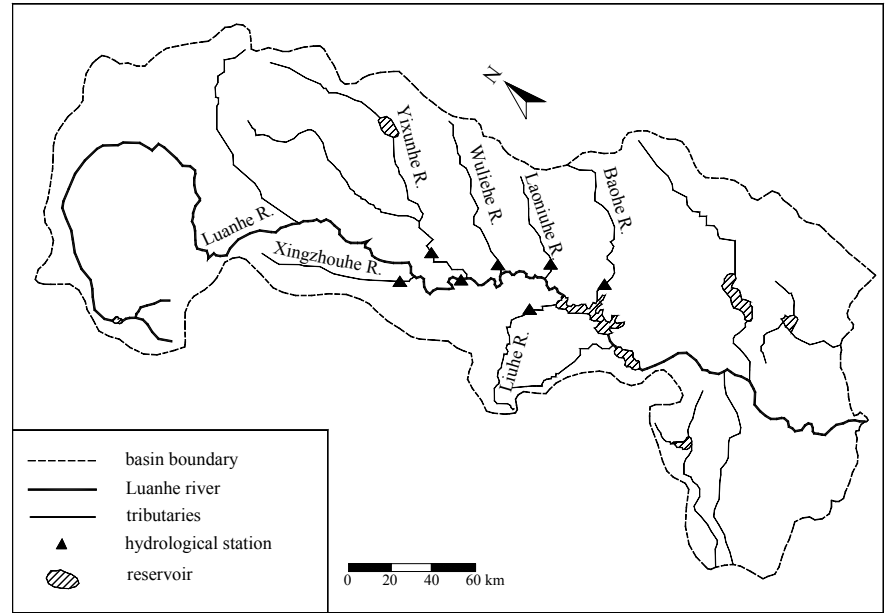

P. Feng and J. Z. Li

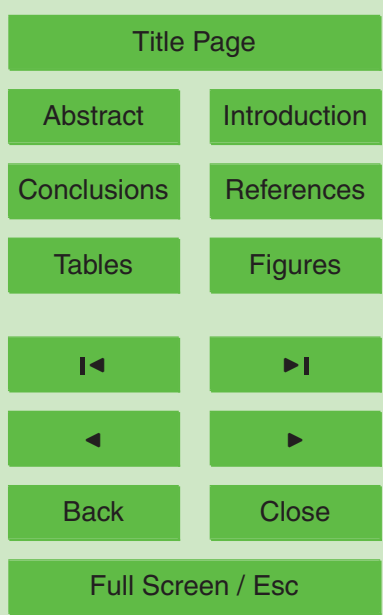

Printer-friendly Version

Interactive Discussion 


\section{HESSD}

$5,1511-1531,2008$

\section{Scale effects on} runoff generation

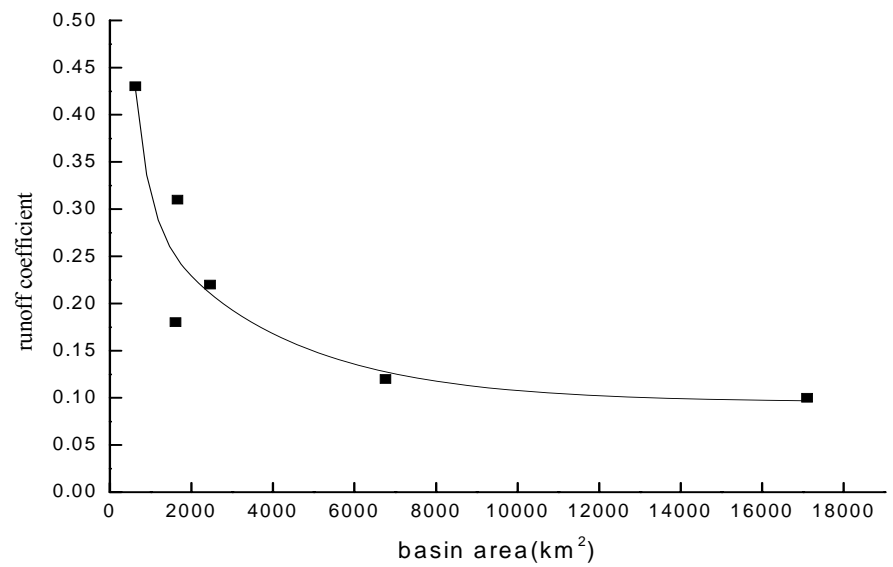

P. Feng and J. Z. Li

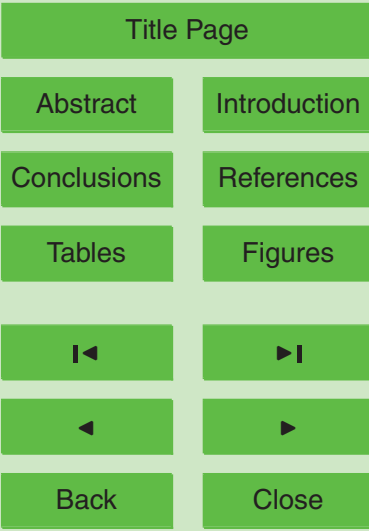

Printer-friendly Version

Interactive Discussion
Fig. 2. Runoff coefficients as a function of basin area for the six sub-basins in the Luanhe river basin.

\section{Full Screen / Esc}

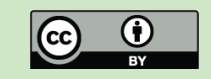




\section{HESSD}

$5,1511-1531,2008$

\section{Scale effects on} runoff generation

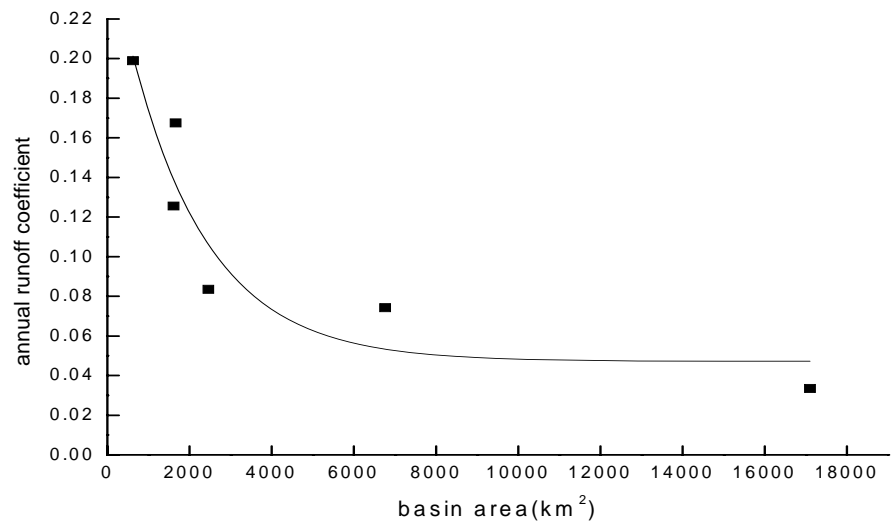

Fig. 3. Annual runoff coefficients as a function of basin area for the six sub-basins in the Luanhe river basin.
P. Feng and J. Z. Li

Title Page

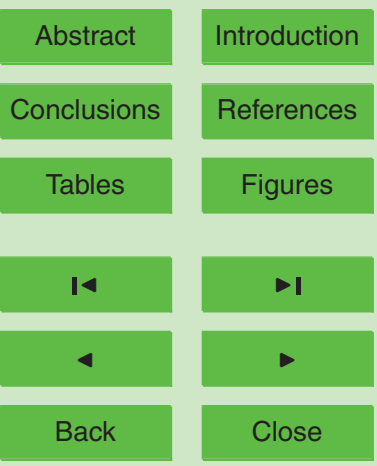

Full Screen / Esc

Printer-friendly Version

Interactive Discussion 


\section{HESSD}

5, 1511-1531, 2008

Scale effects on runoff generation

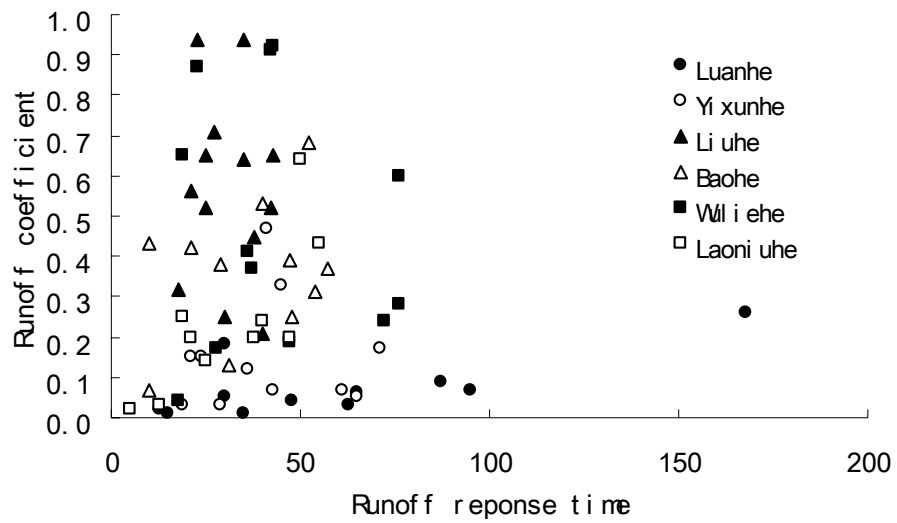

P. Feng and J. Z. Li

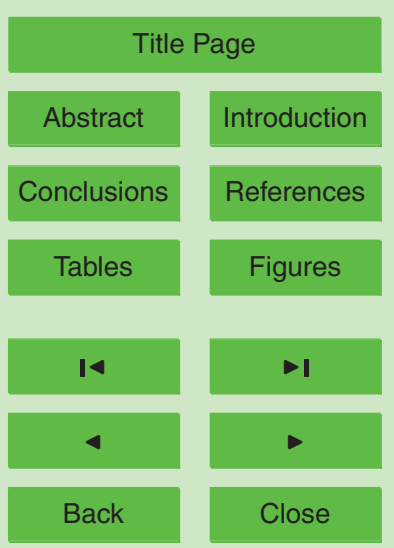

Full Screen / Esc

Printer-friendly Version

Interactive Discussion 